\title{
GOOD GOVERNANCE AND
}

\section{ACCOUNTABILITY: AN ASSESSMENT \\ OF THE MEDIA'S ROLE IN ACHIEVING \\ TRANSPARENCY IN THE 2019 \\ GENERAL ELECTIONS IN NIGERIA}

\section{Aondover Eric Msughter ${ }^{1}$}

\section{Introduction}

Paraphrasing the words of Mahatma Gandhi, one of the objects of the media is to understand the popular feeling and give expression into meaning, which arouse people to the desirable sentiments that will fearlessly expose popular defects. The foregoing statement by Gandhi explains the importance of media in upholding freedom and in expanding education, social reforms and change. Media can inform people, giving them a voice to be heard and heeded to. Democracy requires that people have the right to know the activities of the government, especially the decision of the government that affects their life, liberty and property. Information is important for people to make choices regarding their participation in the State, the market and civil society. Media also fearlessly exposes issues that make people more informed than uninformed. Sufficient information helps them decide rationally and take the right course of action beneficial to them. The media also helps people know what is happening around the globe. By publicizing information, it also makes public services more responsive to the people. Against the backdrop of the foregoing, this paper sets to assess the role of the media in achieving good governance and accountability especially in the 2019 general election.

The provision of section 22 of the 1999 Constitution of Nigeria places an obligation on the press to uphold the responsibility and accountability of

I Department of Mass Communication, Bayer University, Kano, Nigeria. E-mail: aondover7@gmail.com 
government to the people. Thus, democracy can hardly survive and achieve its yearnings in any society where there is no accountability, transparency and the inclusion of the majority of the people in governance and in determining the input into the process of development; all of which are guaranteed through a free and independent media (Auwal, 20I8). Therefore, the responsibility of the media is in holding the government accountable to the people is fundamental to the overall success of democracy.

\section{Justification, Objective and Methodological Approach}

Auwal (2018) established that the contribution of the media in promoting democratic values, good governance and sustainable development has been widely acknowledged. He maintains that there are concerns in Nigeria and other parts of the world about the efforts made by the media to promote these virtues through their power to inform and influence. Based on the preceding observation, this paper aims not only to analyse good governance and accountability in the Nigerian democratic quest, but also to examine the extent to which the performance of the media in the 2019 general election in Nigeria in attaining sustainable development, as well as the media's contribution in strengthening democratic values and good governance. Apparently, the paper is exploratory, as it utilises the descriptive research method whereby relevant literature, documents and records were consulted and analysed based on existing literature to appraise the performance of the media in the 2019 general election in Nigeria. The study is predominantly based on information derived from the qualitative data using secondary sources, such as relevant texts, journals, official publications, historical documents and the Internet, which served as tangible sources of insight into the analysis. However, the inquiry is strictly limited to data found in scholarly journals, books, internet and libraries. The method was used to evaluate such findings with other existing literature on the subject matter. This helps to obtain findings in the works available, check the consistency of such findings and evaluates them against others. Through these methods, the study draws the inferences on the data generated. In addition, an analysis of the strengths and weaknesses of the role played by the media to champion good governance and accountability was given due cognizance. 


\section{Theoretical Underpinning}

Auwal (2018) articulated that, in keeping the public informed, educated and entertained, the media sets standards for public conduct, thereby making possible the participation of citizens in governance. Thus, the role of the media in strengthening democratic ideas, especially in the direction of attaining good governance and sustainable development cannot be ignored. To determine the nexus between the media, democracy, good governance and the development needs of the society, this paper anchors on the democratic participant theory. It takes into cognizance the role media plays in facilitating the active participation of citizens in the process of governance, as a way of exercising their sovereignty, all of which are essential elements of democracy and good governance. However, the main thrust of democratic participant theory centres in its insistence that the existing bureaucracy as well as commercial and professional hegemony in media system be broken down, so as to guarantee easier media access for all potential users and consumers (Folarin, 2002). Notwithstanding, the practical expressions of the theory are many and varied, user participation and interaction, in addition to content plurality at the grass-roots level, constitute the focus of the theory.

The theory was propounded by McQuail, in I987. It's is that the principles of democratisation of the media, for the purpose of accessibility, is by all and sundry. To Asemah (20II) the theory lays emphasis on the need for popular participation and plurality in ownership and access to the media. The bottom line is that, every individual and social group should have access to the media so that they can be able to air their views about the happenings in society. The framework of the theory and other normative theories of the press were formulated largely from a North American perspective, taking note of the distinctive feature of media systems in other parts of the world, like the Nigerian media in enhancing the democratic principles of participatory or inclusive governance, the right to freedom of speech and expression, majority rule and minority rights, among others, all of which are paramount for the attainment of good governance and sustainable development. Therefore, the democratic participant theory may be regarded as the press equivalent of 'grassroots democracy', because under this theory, individual's right to communicate is defended. It is in this regards that the assumption of the theory is found relevant to the study, especially as the media is considered significant in providing opportunities for the participation of citizens in governance, by consolidating absolute involvement of citizenry in the democratic process. 


\section{Understanding Media Institutions in Nigeria}

Over the past decades, the nexus between the press and governments in Nigeria has been a highly contentious issue, drawing attention from a wide range of communication scholars, political scientists and independent research institutions. While perspectives and findings differ on the role of the press in the country as well as its relationship with governments, there is a consensus that the concept of good governance and accountability will be an unrealistic proposition without effective and uncontrolled participation of news sources in disseminating national and political issues.

Meanwhile, Omu (I978) emphasized that the press in Nigeria should be an effective and vibrant independent entity that could be instrumental to achieve sustainable political development goals. For centuries, news sources in Nigeria were involved in promoting political awareness, encouraging civic engagement, sensitizing citizens to national issues and shaping public opinions on a variety of political issues. But it was noted that this role was played under a controlled, confrontational, controversial atmosphere, which compromised the effectiveness of news sources and made objectivity of the press exceedingly difficult. The limited functional scope of communication channels in the country's development efforts through many government administrations was attributed to the censorship and intimidation that were used to curb and control political coverage and the independence of news sources (Agbaje, I992). As discussions on Nigeria's development crisis continue to take an expanded dimension, scholars like Bennett and Lawrence (2008) clearly reinforce the position of previous researchers that a robust and free press is quite capable of dismantling negative images and stereotypes, which the country has faced over a number of years, both at home and abroad.

In a comprehensive report, The World Bank (2009) explained that early development efforts in Nigeria, and other emerging African nations, were grossly unsuccessful and unattainable, largely because of the inadequate role to which the news sources were relegated to play and which resulted in widespread criticism of the national media as ineffective to gather and analyze salient issues. Furthermore, Okoro, in Rantanen (2004), stressed that the establishment of government newspapers in the country weakened the credibility and competitiveness of communication channels, demoralizing the citizens from depending on national news and information. For one thing, government newspapers were better funded, strategically positioned and adequately staffed to cover news and events. While in recent years there has been a proliferation of news sources in the country, it remains to be seen 
whether their journalistic political content, analysis of government programs and political actions and policies will be objectively and critically explained to the citizens (Jibo, I996).

As The World Bank report (20I2) illustrated, Nigeria has a population of over 158 million, which positions the country as the largest and most populous nation in the African continent, representing 47 percent of West Africa's population. The country's diverse and pluralistic structure and composition is fundamentally similar to most African nations, especially in the sub-Saharan region in terms of ethnic groups, linguistic pattern, tradition, values, beliefs and historical origin. With the exception of a few homogeneous nations, Nigeria is one of the numerous heterogeneous African societies that speak several different languages and dialects and have different cultures and political orientation. The English language is the official language and it is widely spoken in many parts of the country as the language of commerce and social interaction. Although the present day Nigeria is composed of 36 states and a Federal capital territory Abuja with a total of 774 local government areas, the country's origin was traced to the evolution of the three dominant ethnic groups (Igbos, Hausas and Yorubas) that have influenced and shaped the it's social, cultural and political experiences. For decades, the country was a British colony until I960 when it gained independence and became a Federal Republic in I963.

Media is the most important and vital element for dissemination of information. Today, radio signals in villages, newspapers as well as Kakaaki on AIT or Good Morning Nigeria on NTA, have made the media spread its roots in an unbelievably manner. Hence, the role of media has become extremely critical for the smooth functioning of democracy, as it helps in forming public opinion on vital topics. This is the reason why the media is termed as the fourth power as it is a non state element aimed at protecting citizens. All forms of media have a specific sets of followers which enable better governance (Oso, Soola and Pate, 20I2).

Nigeria is a developing country with a fairly well-established media industry (Uche, I989). It had a virile press before the colonial advent and has, subsequently, established an electronic media that has a reasonable reach. Thanks to Decree No. 38 of I992, the broadcast industry has been liberalised and private-owned television stations such as African Independent Television (AIT), Desmins Independent Television (DITV) and Minaj Broadcast International (MBI) have been established. A fairly large number of private radio stations have also been licensed and are on air. Thus, going by the numbers alone, one can see that Nigeria has a strong media establishment. 
Beyond the numbers, some factors combine to enhance or whittle down the Nigerian media effect.

While the country continues to experiment with democratization with varying results, much effort still needs to be devoted to building a strong civil, equal and economically vibrant nation. Evidently, more citizen participation in the democratic process is urgently needed as well as the creation of an enabling environment for equal representation of ethnic groups and the presence of independent communication channels or press for objective coverage and dissemination of information (Agbaje, 1992).

Development studies by Voltmer (2000) and Rantanen (2004) indicate that responsible and effective governance is essential for sustainable democracy and political stability in developing nations of Africa, especially in a country like Nigeria, where the citizens and other significant stakeholders have been clamoring for policy reforms, the youths involvement in politics, improved quality of life and a more robust media presence.

Communication scholar and political analyst James (2005) explains that over the past two decades the participatory democratic process has taken a dramatic turn in the emerging democracies in the wake of citizens' agitation for good governance, expanded ethnic integration, independent and vibrant press, increased citizen participation, freedom of speech and informed public debate. More than ever, past and present leaders of Nigeria have consistently indicated a commitment to a sustainable national and political development and have introduced various measures to support their development objectives, social policies and economic agenda.

However, The World Bank (2009) report indicates that the country has not been able to achieve its seemingly ambitious national development programs, because of misplaced focus on tribal and ethnic issues and politics, rather than focusing on an integrated national development that would unify it towards a common national purpose. For example, the development objective in Nigeria shifted in recent times from rural areas, where most of the country's approximately I0०,000 communities reside, to urban communities. Indeed, the uneven distribution of national programs and building of infrastructures in different parts of the country accounts for the growing imbalance in the pace of development in rural and urban communities. 


\section{The Nexus between the Media, Democracy and Governance}

Since the return of the country to democratic rule in I999, Nigerian politicians have evolved a political culture that is characterised by the politics of godfatherism, corruption, misappropriation of public funds and electoral malpractices in order to control state power against the popular will of the masses (Philip, Samson and Ogwu, 20I4). Philip et al (20I4) further argue that a society with vibrant media institutions can strengthen democracy and facilitate good governance. Given that democracy is conceived as a system that operates on the principles of equality, participation, majority rule and minority rights, rule of law and due process, respect for human rights and free and fair elections; there is a need for an institution such as the media to facilitate the entrenchment of these values in the society. Also, the active participation of the people in government, signifying the exercise of their sovereignty as stipulated in the Constitution, is achievable through the media, which provides a free flow of information and viable platforms for the expression of views and opinions.

This could be the reason why Jega (20I4) articulated that, for democracy to thrive in any given society, the media must provide people with access to all the information needed to guide and safeguard their electoral choices. Thus, the media serves as a bridge between government and the citizens in a democratic system. The media, according to Ate (2007), can connect government and the governed and electorate to the candidate in a democratic setting. The central message about media and governance is that the latter dictates the former in the society and both play complementary roles in serving the populace. This forms the basis of the inseparable relationship between the media, democracy and governance.

According to Auwal (20I8), there is a peculiarly intimate relationship between the political and communication process and no institution as sizeable and as influential as the media can escape involvement with government and politics. The media is not only the channel for the transmission of political information and debates, but also a significant player with a direct stake in government regulatory and economic policies, as well as the government's attitude towards free speech and dissent. Moreover, the tripartite relationship which embraces democracy, politics and development are expected to be catalysed by the fourth power of the realm of the mass media (Idemudia, 2008 and Terlumun, 20I0). Although factors such as mutual distrust, excessive secrecy, especially on matters of national interest, undue restrictions imposed through obnoxious legislations, extra-judicial actions, among others 
characterise the relationship between the media and the Nigerian government particularly in the past. This is not far from what Abone and Kur (20I4) described as 'a cat and mouse affair'.

Amidst the challenges influencing this relationship, the media are indispensable in the efforts towards sustaining democratic values and promoting good governance in society. The press has tried its best since independence to monitor governance to uphold the responsibility and accountability of government to the people (Bamidele, 20I2). Since the democratic dispensation, which started in May 29, 1999, the success of democracy is easily identifiable from the measure of press (Baran, 2004). However, it is instructive to infer that, if democracy is to survive and be a fruitful concept, the role of media in sustaining it cannot be overemphasized, and if the media is to have any meaningful role in democracy and governance, they must be free from undue control of government (Sowunmi, 2010). The ultimate goal of media in any society is to serve the public interest and it is therefore evident that a complementary relationship exists between the media, democracy and the process of governance. Media in this context are viable channels that stimulate and foster pressure groups on issues that are in the domain of the public, because pressure groups are the guiding elements of governance.

\section{The Role of the Media in Strengthening Democracy and Enhancing Good Governance}

As established by Auwal (20I8), in a democratic society like Nigeria, the role of mass media is anchored on their famous status as 'Fourth Estates of the Realm'. To corroborate this, the I999 Constitution, stipulates under section 22 that "the press, radio, television and other agencies of mass media shall at all times be free to uphold the fundamental objectives contained in this Chapter and uphold the responsibility and accountability of the Government to the people". The Constitutional provision clearly explains the obligation of the media in a democratic society.

In a democratic environment according to Olusola (2008), the media's purpose extends beyond the basic functions of information, education and entertainment. The media also has the responsibility of sustaining and nourishing the ideals of democratic ethos and to constantly assure and guarantee the protection of freedom of individuals and that of the media themselves, which is the heart of popular participation in liberal democracies. The press can promote democracy by educating voters, protecting human 
rights, promoting tolerance among various social groups and ensuring that government is transparent and accountable, etc.

According to Akinwale (2010), the press helps keep the public informed, it entertains, educates, sets standards and establishes values for public conduct. The popular reference to the media as a 'fourth power' points to its capacity to perform the role of watchdogs, by monitoring those in authority, exposing their limitations and providing checks and balances to other three powers: the executive, the legislative and the judiciary (Nwagbara, 2010). Through the aforementioned functions, the media sets an agenda, organises public debates and discussions and interprets issues to put them in proper perspective in order to make meaning for people, just like the Presidential debates that were organized by the media during the 2019 general election, where Presidential aspirants were invited to talk to Nigerians (Sambe, 2008 and Harcup, 2009). Whether electronic or print (Asemah, 20II), the media has responsibilities to the society politically, socially, educationally and religiously (Akinwale, 2008). The media's duty to individuals, as well as to the society at large is immeasurable. In fact, the media is an important asset to society and when utilised properly can serve as a viable tool for socioeconomic and political development (Abagen, 2009).

\section{Why Media is particularly important for Nigeria in Quest of Good governance and Accountability?}

Since good governance comprises of accountability, transparency, responsiveness, equitability and inclusiveness as well as effectiveness and efficiency, the media has a huge role in ensuring that all of these criteria are met from time to time. Good governance essentially means how public institutions conduct public affairs and manage public resources and the media's role in these is reporting all that transpired to the public domain (Riddell, 20I4). But the media's reports on the 2019 general election was a very commendable efforts and it was most embarrassing to Nigerians that this could occur, even in a country with the facade of a civilized nation.

For a developing country like Nigeria, which still reels with voter's apathy, buying of votes, snatching of ballot boxes and asterism (Nwanna, 200I), the involvement of the media becomes even more important. The backward and ignorance of the poor should make the media emboldened regarding its responsibility to bring them modern ideas for eliminating 
poverty and other social evils like it's doing in reporting issues regarding corruption.

Another reason why the media is of paramount importance for the country is because of the immense disparity that is prevalent (Ferejohn, I999). While a large number of journalists cover the more glamorous and glitzy events and news, less report on the number of deaths or the unemployment scenario. The rationality of media lies in helping the government fight diseases such as AIDS, Polio, Cancer along with promoting latest technologies for the development of its citizens.

The media should be vigilant about the laws of the country and that they are not violated by institutions of the government or any other rogue elements. In this aspect, media in Nigeria has demonstrated its excellence in bringing to book some of the corrupt politicians in recent times. In fact, it has gone the extra mile by putting pressure to ensure that justice is given to victims. A lot of governments across the world have faced charges of corruption highlighted by the media and that has often led to either overthrowing of corrupt administration or bringing in more transparency into the system such as the overthrow of the then Ghanaian president General Acheampong by Jerry Rawlings, Samuel Doe who overthrew the government of Tolbaert in Liberia in I980 and that of Idi Amin who was overthrown by Yoweri Musokani in Uganda. Hence, the fourth power can help in the efficacy of the existing scheme of things as well.

One of the strongest roles of media is that it tries to engage millions of viewers, listeners or readers. In this manner, the fundamental role of ensuring participation of its citizens in the decision making process of the country is done by the media very well. Even with the just concluded 2019 general election, the media provided an avenue for the Nigerian populace to express their views and opinions.

\section{The Media and the Quest for Sustainable Democracy and Good Governance: Examining the Journey so Far}

In their study on the role of mass media in consolidating democracy, Santas and Dogara (20I6) observe that the media contributed immensely to the return of democracy in Nigeria. Thus, the media, through their critical analysis of the military junta, mobilisation of the citizens to participate in entrenching democratic values, exposing cases of corruption, made public officers accountable to the people. Despite the great performance of the media 
in promoting democracy, they faced challenges with border on issues of ethnicity, lack of adequate modern communication gadgets, hassle from pressure groups and the government, ownership questions, corruption and security issues among others. Today, one can safely boast that democracy is gradually taking root in Nigeria with the successful transition from one democratically elected government to another. However, one cannot say Nigeria's democracy has developed, as the media must work assiduously hard to sustain the consolidate the success recorded by the media and the government must take some deliberate and concrete steps in overhauling the entire media industry in the country.

Similarly, Senam and Udo (20I5) assessed the contributions of critical journalism to democratic governance and report that, given the dynamic nature of a technology-driven society, journalism is beyond the conventional practice of reporting based on the $5 \mathrm{WsH}$ and requires more of an in-depth analysis of the information so reported. Critical journalism, according to the authors, has played an invaluable role in the sustenance of democratic governance, especially between I999 and the present era of democratic governance. Such roles include checkmating excesses in governance and bridging the communication gap between the government and the governed. However, the quality and nature of freedom in a nation's media speaks volumes about the quality of it's democracy. Despite the problems facing the Nigerian media, critical journalism greatly contributes to enhancing democratic governance. To continue to remain relevant in this crusade, journalism should strive beyond merely reporting based on the $5 \mathrm{WsH}$ approach but engage in in-depth investigation and unbiased analysis to upgrade the standard from conventional journalism to critical journalism.

In a review of the role of media in good governance, Dunu (2013) argued that media's potential to contribute to good governance depends on the extent it reflects and enforces the principles of good governance as an institution. For the media to contribute effectively in enthroning good governance it must, as a matter of responsibility, apply the basic principles of patriotism, accountability and transparency in the discharge of their duties while upholding the sanctity of truth and fairness at all times. The media themselves must be a credible example of the good governance concept, by upholding professional ethical rules set up through self-regulation and constantly enhance professionalism, be accountable to the public in the way it informs, educates and entertains. In summary, the media should recognise that it's accountable for its actions to the public, its profession and themselves. 
Also, in examining the activities of the media in the fight against corruption and the promotion of accountability in leadership, Santas (20I4) recounts that the Nigerian media has recorded success in bringing public officers to account, by exposing corrupt practices among government functionaries. A good example is the case of Jaafar Jaafar, the editor of online Daily Nigerian newspaper exposing the Governor of Kano Umar Ganduje for $\$ 5 \mathrm{mn}$ bribery allegation from the contractors. However, transparency and accountability are essential pillars of democratic governance and these virtues are significant in measuring the success or otherwise of any democratic system. Apart from the activities of anti-graft agencies in combating corruption, the media are often looked upon as an important institution in the fight against corruption in any system. This draws from their watchdog function of monitoring the actions and inactions of those in power.

It is evident from the literature that since independence, the Nigerian media has been at the forefront of the struggle for the enthronement of democratic values and good governance in the society. The media have undoubtedly evolved and become more active in influencing and shaping the society, especially as their roles complement in nurturing the essential elements necessary for the survival of democracy in the contemporary. In relation to governance, the media holds the government accountable by highlighting and exposing the activities of public office-holders at various levels.

However, there are persistent arguments on whether or not the fourth power in Nigeria is living up to expectations in the quest for true democracy, good governance and sustainable development, exists among scholars and professionals in the media industry. Thus, it is the conviction of this paper, that in spite of these challenges, the media is doing reasonably well in this regard, but with too much emphasis on government accountability, rather than civic or individual responsibilities, considering that tasks of promoting democracy, good governance and development lies not only with government but citizens as well. Citizens also have a role to play in complementing the efforts of government. Accordingly, this paper examines the performance of the media in the 20I9 general election in Nigeria by looking at its role during and after the election as well as respect for human rights and the rule of law all of which are requisite for achieving good governance and sustainable development in the society.

Apparently, the media have a responsibility to ensure fairness in the electoral process, respect for human rights and the rule of law. Haruna (20I4) is of the view that most people learn about issues and events from the media and it has immense power to set society's agenda, because it is, 
arguably, the most important source of information and knowledge. The media is a very important asset a society should have, because it stimulates growth and improves the economy of a nation as well as being a platform for the exchange of ideas and debates. The importance of media to the electoral process and in ensuring respect for human rights and the rule of law cannot be ignored, as it contributes significantly to the political processes at national and international levels. The media's three basic functions in this regard include: surveillance of the world to report on-going events, interpretation of the meaning of events and socialisation of individuals (Olayiwola, I99I).

Despite the biased and partisan nature of the coverage of political activities, as well as the electioneering campaigns of the 20 Ig election resulting in crises in some parts of the country, the media played a major role in ensuring that Nigeria remains united amidst security challenges. The incorporation of new technologies into the electoral process, like the biometric card reader and the use of broadcast and other social media platforms, during and after the elections, especially in the collation and announcement of result and the efforts of the media in educating, as well as mobilizing public support in the entire process, point to the fact that the media remains dutiful in promoting democratic values and enhancing the credibility of Nigeria's electoral process. The recent agitations by civil society organisations and pressure groups for the autonomy, are among other instances where the contributions of the media in providing platforms for concerned stakeholders to debate toward enlightening the general public, remains sacrosanct in a bid to promote good governance.

\section{Conclusion and Recommendations}

From the words of Siegel (2008), the role of media has risen over time and it would gain more importance in the times to come, as many across the world still yearn for better governance, or at best governance itself and not autocratic rule. While media does highlight some of the concerns from time to time, it does not delve deeper into the real issues. The checks and balances which media ensures by reporting issues in an objective manner can go a long way in ensuring that governance by government would be fair and fruitful.

As such, the Nigerian media can play a more effective role in the quest for good governance and accountability government if professional standards are followed. In particular, the media needs to show more com- 
mitment to the universal ethics of the profession with strong attachment to the sacredness of facts. Once the facts have been subjected to disrespect, the way is wide open for all sorts of professional misconduct, ranging from "protocol journalism" to bribe taking, to be perpetrated. In the process, important considerations are compromised, including good governance and accountability in government. These are the contemporary ethics problems of the Nigerian media.

Apparently, democratization in contemporary Nigeria appears unattainable if Nigeria's stakeholders in urban and rural communities are not fully and actively engaged in development needs and planning. The citizens of Nigeria, in particular, must be made to appreciate the importance of participating in the political process and challenging unpopular government decisions and actions. The national press and other news sources should play the crucial function of advocating for citizens' understanding of government activities, public policies and development plans. The paper concluded that the media is the major pillars of democracy and the citizens remain the most important stakeholders in the democratic process. Consequently, this paper recommends as follows:

I) Achieving good governance requires the understanding and participation of very member of the society. Thus, the media must serve as a bridge between the government and citizens in order to champion the democratic processes. This is so because media is an independent institution and the most powerful weapon to make this a reality.

2) Adherence to professional ethics and the principles of social responsibility by the media can go a long way to foster good governance and accountability in a democratic system.

3) Forthcoming researchers in the area should adopt other methods aside secondary data to expand the fraction of literature in the area.

\section{REFERENCES}

Abagen, F.T. (2009). The mass media and the evolution of a viable social and political order. Nigerian Journal of Communication Research, I(I): 39-55. 
Abone, G.O \& Kur, J.T. (20I4). Perceptual influence of freedom of information act on journalism practice in Nigeria. Arabian Journal of Business and Management Review (OMAN Chapter), 3(7): 23-35.

Agbaje, A. B. (1992). The Nigerian Press, Hegemony and the Social Construction of Legitimacy. New York: The Edwin Mellen Press.

Akinwale, A.A. (2010). Repression of press freedom in Nigeria democratic dispensation. African Development, XXXV (3): 47-70.

Asemah, E.S. (20II). Mass media in the contemporary society. Jos: University, Press.

Ate, A.A. (2007). Media coverage of April 2007 elections: a post mortem. Unpublished work.

Auwal, A.M. (2018). Mass media, democracy and the imperatives of good governance in Nigeria: An Appraisal. Canada University Press, Concord Ontario, Canada.

Bamidele, G. (2012). Mass media and national security in Nigeria. The Press, I5. Abuja: Nigerian Press Council (NPC).

Baran, S.J. (2004). Introduction to mass communication: media literacy and culture (3rd ed.). New York: McGraw-Hill.

Bennett, W. L. \& Lawrence, R. G. (2008). 'Press freedom and democratic accountability in a time of war, commercialism, and the Internet'. In The Politics of News. The News of Politics, eds. Doris A. Graber, Denis McQuail and Pippa Norris. Washington: CQ Press.

Dunu, I. (20I3). Good governance in Nigeria: what role for the media. European Scientific Journal, 9(32): I78-I97.

Ferejohn, J. (I999). Accountability and authority: towards a model of political accountability', in A. Przeworski, B. Manin and S. C. Stokes (eds.), Democracy, accountability, and representation. London: Cambridge University Press.

Folarin, B. (2002). Theories of mass communication: an introduction. Abeokuta: Link Publications.

Harcup, T. (2009). Journalism: principles and practice (2nd ed.). London: Sage Publications Ltd.

Haruna, M. (20I4). How to meet the public expectations of the media for free, fair and credible election 2015. The press, 22, Abuja: Nigerian Press Council (NPC).

Idemudia, R.U.P. (2008). Mass media in national development and integration: an appraisal of democratic, social and political impact in Nigeria, 
I999-2007. In F.I.A. Omu \& G.E Oboh (eds.). Mass media in Nigerian democracy (pp I32-I5I). Ibadan: Stirling-Horden Publishers Ltd.

James, B. (2005). The media and good governance. Paris: UNESCO Jega, M.A. (20I4). 20I5 elections: INEC and the media. The Press, Issue Number Twenty-Two. Abuja: Nigerian Press Council (NPC).

Jibo, M. (2000). The media and Nigerian politics. Unpublished M.Sc. Thesis, University of Birmingham.

McQuail, D. (20I0). McQuail's mass communication theory (6th ed.). London: Sage Publications Ltd.

Nwagbara, U. (2010). The Nigerian press, public sphere and sustainable development: engaging the amnesty deal in the Niger delta. Journal of Sustainable Development in Africa, I2(3): I4-27.

Nwanna, O. (200I). The unfinished question for the President. The Post Express (Lagos), 3 August.

Olusola, I.O. (2008). Mass media and democratic governance in Africa. in F.I.A. Omu \& G.E. Oboh (eds.) Mass media in Nigerian democracy (pp. III-I22). Makurdi: Aboki Publishers.

Olayiwola, R.O. (I99I). Political communications: press and politics in Nigeria's second republic. Africa Media Review, 5(2), 3I-45.

Omu, F. A. (I978). Press and politics in Nigeria I880-I937. London: Longman.

Oso, L., Soola, O. \& Pate, U. (2012). Media, governance and development in Nigeria: Issues and trends. USA: LAP LABERT Academic Publishing

Philip, A.A., Ogwu, H.P. (20I4). Godfatherism, party politics and democracy in Nigeria: issues and challenges. Journal of Good Governance and Sustainable Development in Africa. (JGGSDA), 2(2).

Rantanen, T. (2004). The media and globalization. London: Sage.

Riddell, P. (20I4). Impact of transparency and accountability', in Bowels, N., Hamilton, J. T. \& Levy, D. A. L. (eds), Transparency in politics and media: Accountability and open government. London: I. B. Tauris \& Co Ltd.

Sambe, S.A. (2008). Essentials of news writing, reporting and editing. Makurdi: Philsat Communication.

Santas, T \& Dogara, O.J. (20I6). An appraisal of mass media role in consolidating democracy in Nigeria. African Research Review, Io(I), 73-86.

Senam, N. \& Udo, I. P. (20I5). Critical journalism and democratic governance in Nigeria. Research on Humanities and Social Science, 5(I0): 44-49 
Siegel, P. (2008). Communication law in America. New York: Rowman Littlefield

Sowunmi, F.A. (20I0). The role of media in curbing corruption in Nigeria. Research Journal of Information Technology, 2(I): 7-23.

Terlumun, T. E. \& Tivlumun, N.G (20I0). Introduction to mass media: A handbook. Makudi: Aboki Publishers.

The World Bank Reports (2009 and 20I2). Available online at http://web. worldbank.org.

Uche, L. U. (1989). Mass Media, People and Politics. New Delhi: Concept Publishing Company.

Voltmer, K. (2000). Constructing political reality in Russia. Izvestiya-between old and new journalistic practices. European Journal of Communication I4(4): 469-500.

\begin{abstract}
The media has, over the years, been significantly active in the country's political and democratisation processes, especially in the 2019 general election. Apparently, mass media is the pillar upon which democracy stands, thrives and survives. Therefore, the significance of the media in a democratic setting cannot be underscored. Against the backdrop of the foregoing, this paper examines good governance, accountability and the role of media in the 20I9 general election, in Nigeria. This paper also pins down that media's potential to contribute to good governance and accountability depends on the extent it reflects and enforces the principles of good governance and accountability as an institution. The paper assesses the role of the media in achieving transparency and accountable government in the 2019 general election with regard to the coverage, while highlighting some relevant issues that serve as the bottleneck in the paper. It also interrogates the nexus between the media, democracy and governance, concluding that the media contributes significantly to socio-political development in society and it is barely possible for any society to achieve its yearning and aspirations without the media. The paper establishes that transparency and accountability in governance can only be achieved through the influential power of the media.
\end{abstract}

\title{
Keywords
}

Accountability; Corruption; Good Governance; Media and Sustainable Democracy. 